\title{
The spatial consequences of the housing affordability crisis in England.
}

Abstract: This paper discusses the impact of housing affordability on the spatial distribution of productivity and wages. The key theoretical contribution is to phrase the problem as an issue of the composition (rather than the level) of housing demand and link it to heterogeneous preferences and characteristics of households. Using a simple simulation methodology the study estimates levels of amenity values and wages that would make current house prices as affordable as they were in 1995 in all English Local Authority Districts. Although average wages would be unlikely to increase if housing was more affordable, productivity across England would probably be higher as the spatial distribution of economic activity would change. The key conclusions are that 1) unaffordable housing has significant economic implications and 2) policy aimed at improving housing affordability should consider targeting housing demand as well as supply.

Keywords: Housing affordability, Housing demand, Local productivity, Household migration

\section{Introduction}

House prices in the most productive cities and regions around the world are growing much faster than wages and many developed countries including the UK, Australia, Canada and the US appear to be facing an 'affordability crisis' (Fingleton et al. 2018, Fingleton 2008, Skaburskis 2004). As similar issues are reported by developing nations including China, Brazil and India (Fruet 2005), it is apparent that housing affordability is becoming a universal issue in urban development. It could constrain regional economic growth as it makes certain locations inaccessible and affects their labour markets. For example, Meen (2000) suggests that unaffordable housing reduces agglomeration benefits while Stone (2006) contends that it leads to spatial inequality. While these claims have made unaffordable housing a critical political issue, it is unclear what the economy would be like if housing was more affordable. In fact, it is not universally accepted that affordability is strictly and economic problem since house prices are purely an expression of the willingness to pay for housing there is no economic problem of prices being too high as those who purchase houses ae clearly willing and able to pay (Glaeser and Gyourko 2002). This paper argues that unaffordable housing limits local productivity growth by influencing labour supply and investigates the impact this process has on regional economies.

Although there is no universally accepted definition of affordability, most debates usually concentrate on the price of owning a house adjusted to local economic standards (Stone 2006). Its conventional measure is based on the ratio of average house prices to average annual wages, which shows that affordability is determined by both labour and housing markets. However, the economic literature on the topic focuses mainly on housing supply and how it fails to adopt to the growing demand. Glaeser and Gyourko (2002) show that for housing costs to rise above an average national cost of construction, planning must restrict development of new dwellings. Indeed, local polices on planning, transport and land development have been shown to influence house prices as well as their wage elasticity (Hilber $\&$ Veremulen 2016). While this explains why prices would respond more strongly to demand shocks in places where development is restricted, even with no change in the housing stock, growing demand is a prerequisite for increasing prices. However, affordability responds differently to different demand shocks. For example, rising demand may be driven by local residents becoming better off and this does not necessarily change the affordability ratio (if both house prices and wages increase). The focus of this paper is on factors that affect demand but are not directly related to wages. This study follows the economic tradition of calling them 'amenities' and this broad definition includes the usual 
consumption and cultural amenities but also the 'financial' amenities of an attractive investment market, the 'prestige' amenity factor and all other unobserved determinants of house prices. This allows considering affordability to be a manifestation of housing demand being driven by the value of amenities rather than wages. In this context, the issue can be presented as a result of the fact that households have different preferences, abilities and wealth. Arguably, if the level of housing demand observed in real data was driven by wages, there would be no affordability crisis. Therefore, the impact of the affordability crisis can be estimated by comparing the current economy to a simulated scenario where house prices are driven mostly by wages.

The first step of creating an economic scenario in which houses are affordable is, to eliminate differences between households in terms of their preference for amenity, ability to pay for housing and productivity. Doing so allows assuming that drivers of housing demand in all locations are identical and that its level is reflected in prices. The focus of this study is therefore on residents and housing markets of Local Authority Districts which are the smallest locations in England which constitute relatively homogenous housing markets and for which data is available.

Even with homogenous households, modelling housing markets is difficult and there appears to be no accurate method of predicting house prices. Supply and demand interactions are difficult to model due to numerous market inefficiencies that characterise real estate markets (Wheaton 1990), spatial interactions between housing markets (Jeanty et al. 2010), commuting effects on demand (Fingleton 2008) and various environmental effects (Brasington \& Hite 2005). In contrast to Hsieh and Moretti (2016), who build an equilibrium model of urban economies and estimate changes in production, house prices and population, this paper uses observed values of all these variables to establish an equilibrium between supply and demand in housing and labour markets. The scenario in which affordability is not an issue is developed under the same population distribution and house prices as observed in actual data. Under these conditions, ensuring that each housing market offers the same affordability ratio allows estimating wages required to support it in each area. However, even with homogenous households affordability ratios should vary between locations (Meen 2008). As population density influences productivity, wages and amenity values, the affordability ratio should be allowed to vary with density. To estimate how density influences affordability the study uses a model of congestion effects. With homogenous households, the impact of overcrowding is relatively simple to estimate and knowing what the impact of density is on the amenity value allows reflecting this effect in wages.

The final step in estimating wages in the simulated scenario is to relax the assumption that house prices are the same as observed in current data. This is achieved by calculating an alternative distribution of house prices and population using their values form 1995. Historical data shows that this was the year when housing affordability ratios in England were at their historical lows and varied little over space. Ensuring that populations and house prices in each analysed location follow national growth rates offers a spatial distribution of the current population and housing demand that supports a more affordable housing markets.

Simulation results show that imposing the average affordability ratio on all districts in England and keeping house prices unchanged results in wages increasing in the least and decreasing in the most affordable locations. As they have different populations, the net effect on England's productivity (defined as the average wage in the country divided by its total population) is an increase of over $58 \%$. However, those values are driven primarily by historically high house prices that differ significantly over space. Therefore, these estimates offer little practical insight. When simulations are based on historical records, amenity values are closer to levels expected by traditional economic models. Simulating wages under these conditions results in the average wages in England being statistically 
the same as they are today but productivity increasing by as much as $66.7 \%$. This is a result of workers in locations with lower populations receiving significantly higher wages. The economic significance of this result is that it suggests that if households' location decisions are based on heterogeneous characteristics, economic activity is likely to concentrate in the densest locations. This phenomenon increases wages, population and house prices in the most attractive locations but reduces them disproportionally in the rest of the country. Overall, this results in some increases in local and national wages and productivity being forgone. It also leads to housing affordability worsening in all areas.

The study does not attribute the affordability crisis to any specific economic or social policy, real estate market failure nor suggests a direct solution to the problem. Instead, it argues that it is caused by heterogeneous preferences for amenities and abilities to pay for housing. The research focuses on investigating what wages and productivity would be like if house prices were driven primarily by wages. The results have interesting policy implications as they suggest that popular strategy of addressing affordability issues by building new houses in the most unaffordable locations may not be an effective solution to the problem. Instead, it appears that demand-focused polices may be a valid alternative. Although more research is required to identify what approaches would be optimal, providing the most valuable amenities in locations where housing demand is low appears to be the easiest approach to distribute demand more equally across space. The alternative would be to lower the value of incentives to move to the most unaffordable locations by taxing the amenities that drive affordability ratios. A combination of the two approaches would involve removing (or taxing) an amenity from an unaffordable location and relocating (or funding its provision) it to an area where housing demand is low.

The rest of this paper is divided into seven parts. Section 2 defines and discusses the concept of housing affordability. Section 3 develops a theoretical framework. Section 4 presents the simulation strategy. Section 5 discusses data. Section 6 estimates parameters for the simulation. Section 7 presents and discusses simulation results. Section 8 concludes.

\section{Affordability: definitions, stylized facts and economic effects.}

Although there are several different definitions of housing affordability, this study uses the ratio of the average house price to the average annual wage. The main advantage of this approach is the fact that it is easy to conceptualise and calculate. It also provides an easy method of quantifying the abstract concept in a way that allows comparing different housing and labour markets. Finally, it is adopted and used by the UK government which makes the results and the analysis of this study directly applicable. This method is, however, not a perfect measure of housing affordability and, as argued by Stone (2006), has several disadvantages. First, it operates with averages which are not always reflective of the values faced by households that move into an area. Wages are usually contracted on a long-term basis so the current average is not always what newcomers can receive. Second, the ratio approach does not capture the burden housing costs place on residents, as it equates a high proportion of wage with a high cost. In practice, households with high incomes may have a very different perspective on what proportion of their budgets they can afford to spend on housing than low-income households. An alternative is to use the 'residual income' definition of affordability and establish a level of income that provides acceptable living standards and define housing as unaffordable if it pushes local households below that point (Bernstein et al. 2000). Adjusting that threshold for different sizes and types of households appears to be one of the most comprehensive measures of affordability. Its practical applicability, however, is limited by the fact that the poverty threshold is not only difficult to define and estimate but also changes over time. This makes the ratio approach much more convent to use in practical studies. Other definitions of affordability (defined by Stone 2006) include relative affordability (focused on family income rather than wages) and subjective 
(based on the fact that different households may be affected differently by the same house prices). While the lack of a universal definition does not stop affordability from being an important social and political issue, its makes its economic impact unclear.

\section{Housing supply, wages and endogenous amenity value}

The economic literature discussing housing affordability tends to focus on the failure of real estate markets to adopt to demand. This places an emphasis on analysing determinants of housing supply and various factors that constrain it. A number of different studies argues that affordability is a problem of housing supply and that providing new dwellings could help solve the problem. Over a decade after its publication, the Barker Report (Barker 2004) which was amongst the first studies to suggest this approach, continues to influence both researchers and policy makers. For example, Bramley (2007) argues that only a considerable increase in housing supply stimulated by public and private investment can lead to reducing affordability ratios in England. Meen (2011) builds a complex model of housing policy and affordability. The results show that increasing housing stock can improve the price/wage ratio and he concludes that this should be the policy approach. Finally, Barker (2008) and Withehead (2006) argue that the government should be actively attempting to implement polices focused on increasing housing supply if the affordability crisis is to be addressed. Indeed, in England the government policy is to build new houses in areas where the affordability ratio is the highest (Meen \& Andrew 2008). Housing supply restrictions are also a common theme in many economic studies of housing affordability and strict planning policies are often blamed for causing or contributing to prices outpacing wages (Bramley 2007, Meen \& Andrew 2008). Within this discussion two main arguments appear to be receiving the most attention: 1 ) restricting development essentially imposes a tax on housing construction and causes house prices to rise above their normal construction costs (Glaeser and Gyourko 2002) and 2) restricting housing supply leads to an increase in wage elasticity of price and creates house prices that are much more volatile than wages (Hilber and Veremulen 2016). The first argument rests on the premise that housing can become unaffordable only if its price is artificially inflated. Assuming that when prices remain at construction costs housing is affordable allows attributing high prices to supply constraints. However, it does not necessarily cause high affordability ratios as these will also be determined by how the restricted supply affects wages. One example of this interaction could be that restricting the supply of developable land increases population density where construction in permitted. Density is key to all modern models of urban economics and has been shown to lead to increasing productivity. Therefore, reducing the amount of developable land can be seen as increasing both wages and prices and not affecting affordability. The point here is that the productivity benefits of density on wages outweigh the impact of restricted supply on house prices. The second land-restriction argument accounts for this process. It assumes that house prices are driven by wages and that a steeper housing supply curve increases price volatility. Consequently, increases in wages can lead to disproportional increases in house prices and change the affordability ratio. In this model, higher wages created by density create unaffordable housing even when prices remain at their construction costs. This approach does not, however, explain why households from the unaffordable locations would not simply relocate to places where house prices are lower. It tacitly assumes that restricting the amount of housing development impacts amenity value which changes endogenously as house prices overrespond to shifts in wages. This is best shown in Roback's (1982) spatial equilibrium where the utility of a location (U) is given by the sum of wages (W) and amenity value (C) reduced by the cost of housing $(\mathrm{H}): U=W+C-H$. 
Assuming constant utility, in order for house prices to increase faster than wages the difference in their change has to be reflected in the amenity value ${ }^{1}$.

One reason for affordability ratios to increase is if amenity value change exogenously and the corresponding reaction of wages is insufficient. An extreme example of this process occurring in London is the increasing number of houses in the Royal Borough of Kensington and Chelsea (Sa 2015) owned by wealthy foreigners. The utility they derive from buying a house in one of the most unaffordable places in the world is unlikely to be related to wages and if it has any impact on income of the local residents it is likely to be moderate. A less extreme example can be a household with children paying a premium to move into a good school district. Assuming that it is just as productive as other households, its preference for that particular amenity increases house prices but has little impact on wages ${ }^{2}$. Finally, if two households of equal productivity and preferences compete for the same house (or job) the one with more wealth is likely to win the bidding process as its decisions are less constrained by the level of the wage.

In all of the above examples is an increase in the value of amenities casues growing affordability ratios. While the value of the ratio does not allow identifying the exact drivers of the underlying economic changes, it appears that high affordability can be an indicator of housing demand being dominated by amenity value rather than wages. The key drivers of changes in amenity values appear to be differences in preferences and wealth of households. This has important implications for location decisions and, consequently, labour markets.

\section{Affordability and labour effects}

Unaffordable housing has been claimed to have numerous social and economic consequences stemming mainly from the restrictive influence it has on household migration. Muellbauer and Murphy (1997) note that over-inflated house prices lead to regional labour mismatches which cause losses in efficiency. This is best exemplified by the challenges of attracting key workers to the most unaffordable locations in England reported by many public institutions. The Housing Green Paper (DETR, 2000) highlights a problem of key public sector workers not being able to buy houses in the most unaffordable areas. A later report identifies these occupations as nurses, teachers, police officers and support staff, prison and probations officers, fire and essential services officers, social workers, planners, and some local government health service workers. Critically, the problem is not identified as one of their wages being too low but as of housing prices being too high in comparison. As salaries of those groups remain adjusted to local standards, some areas do not allow the key workers to pay for housing. Muellbauer and Murphy (2008) attribute this issue to a rising value of local amenities that restrict household migration. Numerous studies of how English households make their location choices note that income is a critical determinant of thier decision to move (Hughes and McCormick 2000). To examine how people choose where to locate, Meen (2000) developed a complex econometric model of those decisions. He finds that, in addition to a number of control variables, location preferences of high-income households are the key determinant of overall migration. A similar conclusion is reached by Gyuorko et al. (2013), who report evidence that spatial sorting of high income households contributed to affordability problems in the US. The critical implication is that while the households with higher income can decide where to locate, the poorer ones are left

1 In the interest of space the rich literature on the Roback spatial equilibrium model is not discussed in this paper. A good review of theoretical and empirical literature on this topic can be found in Evans (1990) or Graves and Mueser (1993).

${ }^{2}$ As shown by Glaeser et al (2005) the impact on wages will not be zero but it is likely to be less than equivalent to the impact on house prices. 
'trapped' in locations where they can afford to live. In this environment not all households can move to areas where they are most productive. While in Meen's research the most productive households appear to be moving to areas where they prefer to live, it is unclear if they do so to maximize their productivity. The key message from this study is that location choices are not determined solely by utility maximization but are also influenced significantly by the resources available to the moving households ${ }^{3}$. This constraints the labour market in the most unaffordable locations as only those with sufficient independent wealth are able to move there (Szumilo and Vanino 2018).

For example, in order to afford a mortgage a household has to earn a certain proportion of the price of the asset as a wage and have sufficient savings for a deposit. In areas where the affordability ratio is high, it is unlikely that households that are offered average wages will be able to use them to secure a mortgage. The wage required to obtain a mortgage $\left(W_{m}\right)$ in an area with house price $\mathrm{H}$ can be defined as $W_{m}=s H$, where $\mathrm{s}$ is a constant set by credit markets. Critically, this shows that a high house price to wage ratio may make it difficult for households to move into an area if the wage offered by the location is lower than $W_{m}$. The average wage offered by the location is set by its productivity and labour supply as firms set wages using their marginal cost of production $W_{c}$. In efficient housing markets $W_{m} \leq W_{c}$ so that all households that earn the average wage can afford to buy a house in the area. However, if affordability ratios are high, the wage required to secure a mortgage may be higher than the remuneration offered by local firms. This means that households may not be able to move into an area that would offer them a higher wage and that firms are unable to expand employment simply because housing is too expensive. This can be represented as an anomaly in labour supply which makes it inelastic to wages. This shows that unaffordable housing has significant economic consequences as it limits the ability of households to locate themselves in areas where they would be most productive. This idea can be expressed more formally in a general theoretical model.

\section{The theoretical framework}

Changes in affordability are unlikely to be a direct result of shifts in any single variable but are an outcome of its influence on both house prices and wages as well as an interaction between the two. Modelling house prices and wages is beyond the scope of this paper but both are explored in numerous other studies (Glaeser \& Gyourko 2002, Shiller 2007, McMillen 2008).

Blaming rising housing costs for low housing affordability can be misleading if wages expand accordingly. Defining affordability as the ratio of house prices to wages shows this explicitly. A high value of that ratio does not imply that houses are more expensive than in other areas but simply that they are expensive compared to the purchasing power provided by the wages offered in the location. Therefore, high affordability ratios do not necessarily mean that houses are expensive but it certainly indicates that the proportion of the price that is not accounted for by wages is high. This approach shifts the focus away from price levels and towards the composition of demand. By following Roback (1982) and defining the difference between house prices and wages as amenity value of locating in area $i$ at time $t$, the affordability ratio can be written as:

$$
\frac{H_{i t}}{W_{i t}}=\frac{C_{i t}}{W_{i t}}+1
$$

Wages can be represented as a function of productivity and labour demand. This can be shown by using a simple production function $f(L)$ that assumes that the only factor of production is labour where $L$ is labour input. This means that defining $A$ as productivity allows the output $y$ to be given by

\footnotetext{
${ }^{3}$ Note that the cost of moving includes differences in house prices between origin and destination locations.
} 
$y=A f(L)^{4}$. Productivity can be treated as a function of intrinsic values of national and regional productivities. In this framework, profit maximizing firms will set wages to $W_{t}=A_{t} f^{\prime}\left(L_{t}\right)$ (1). This allows the affordability ratio to be written as:

$$
\frac{H_{i t}}{W_{i t}}=\frac{C_{i t}}{A_{i t} f^{\prime}\left(L_{i t}\right)}+1
$$

This model assumes homogenous households and does not allow for high affordability ratios to influence labour supply due to heterogeneous preferences or differences in wealth. Affordability is expected to be a manifestation of migration decisions and, therefore, identify locations where the key variables are predictably determined by the underlying market dynamics.

\section{Estimation approach}

The empirical objective is to estimate a scenario in which house prices are not dominated by an unknown process and rely on unmeasurable heterogeneous preferences. Therefore, the first step is assuming that households are homogenous in their preference for amenities and value all types of amenities in the same way. Implicitly, by focusing solely on characteristics of places the model also assumes that all households have identical productivity. In practice, the assumption means that households also have a uniform affordability preference and identical abilities to pay. The critical implication of this assumption is that differences in affordability are driven by heterogeneity of locations and that households sort themselves until wages and prices reflect all those features. While random deviations from this assumptions would not affect the impact of this sorting on the economy, a systematic bias may influence it. For example, if (as suggested by Glaeser and Gyourko 2002) more productive workers prefer to cluster together, the forgone contribution to productivity of a marginal household priced out of an area where productive workers live would be higher than pricing out a marginal household from a place where less workers reside. Another implication is that productivity may be influenced by preferences for amenity ${ }^{5}$. Therefore, the implication of assuming homogenous households is that the economic impact of restricting entry to an area is dictated by the characteristics of the location and not its residents.

Another critical assumption is that for each location the average house price and total population are fixed at their observed values. This ensures that the spatial equilibrium holds and that the level of housing demand in that location is realistic and includes changes in supply as well as commuting patterns. In this framework, households do not migrate between locations. Instead, they are assumed to have already moved and expressed their housing demand for housing in house prices. Because in this scenario households are homogenous, house prices reflect all differences between locations including commuting options. Values observed from real data are referred to as 'actual' while 'simulated' values are the hypothetical counterfactual.

The minimum condition for housing to be affordable is that $W_{m}=W_{c}$, so the minimum average wage and maximum amenity value that satisfy this condition can be obtained from setting a fixed affordability ratio in all locations in England. The rationale behind this approach is to remove the preference for amenity value as a driver of migration and to assume that amenity value is perfectly correlated with wages earned at the location. So the simulated level of wages $W^{\prime}$ can be obtained from:

\footnotetext{
${ }^{4}$ Adding other factors of production does not affect the conclusions but makes the analysis more complex so this study focuses on the simplified case.

${ }^{5}$ For example, in places where foreign ownership inflates prices but contributes little to productivity
} 


$$
W^{\prime}{ }_{i t}=H_{i t} \frac{\bar{W}_{t}}{\bar{H}_{t}}
$$

Where $\bar{W}_{t}$ and $\bar{H}_{t}$ are average wages and house prices in England (across all locations) at time t.

This implies several important assumptions. First, the simulated value of amenities is proportional to wages offered at the location. This reflects the expectation that households that earn more have higer residual income and are likely to attract different amenities. For example, households with higher incomes are more likely to invest in renovating their houses so that the quality of the housing stock in locations where wages are higher will be different. Importantly, it is assumed that this difference is driven purely by wages and dictated by the average affordability ratio. This means that households that move into a higher-wage area are able to afford the same level of amenities as its current residents and are not priced out of the market because of their high value.

A natural downside of this solution is that it ignores all determinants of housing demand that are not related to affordability. For example, it equates productivity in locations with the same population and house prices but different land areas. As areas with higher population density have been shown to be more productive (even with homogenous households), the simulation should reflect that difference. From the production function specified above, wages are already defined as a function of productivity and labour supply. However, by choosing to measure productivity as the average wage earned by residents of an area divided by its population, it is possible to reflect how productive its inhabitants are. This is equivalent to setting the labour supply function to be a function of population $f\left(L_{i t}\right)=L_{i t}{ }^{2}$ and assuming that the labour force is half the size of the local population $2 L_{i t}=K_{i t}$. Consequently, productivity $(A)$ can be defined as:

$$
A_{i t}=\frac{W_{i t}}{K_{i t}}
$$

As both productivity and amenity values have been shown to vary with density, house prices can be written as:

$$
\begin{gathered}
A_{i t}=a_{i t} d_{i t}^{\omega} \\
C_{i t}=c_{i t} d_{i t}^{\gamma} \\
H_{i t}=c_{i t} d_{i t}^{\gamma}+a_{i t} d_{i t}^{\omega} K_{i t}
\end{gathered}
$$

where $c_{i t}$ and $a_{i t}$ are intrinsic amenity value and productivity of location $\mathrm{i}, \mathrm{d}$ is population density and $\gamma$ and $\omega$ are agglomeration spillover effects. This shows that areas with the same population and house prices but different land areas can differ in wage levels and amenity value. It also implies that obtaining an estimate for either $\gamma$ or $\omega$ allows inferring what the other spillover effect is (with known house prices, density, population and intrinsic values of productivity as well as amenity). Using a fixed affordability ratio sets the value of amenities to a maximum that would maintain affordable housing. Since the value of $\gamma$ is expected to be negative (Ciccone 2002), the maximum amenity threshold can be used as the intrinsic amenity value of the location so that $c_{i t}=H_{i t}-W^{\prime}{ }_{i t}$. Using this logic and equation 2 the new simulated wage can be defined as:

$$
W^{\prime \prime}{ }_{i t}=H_{i t}-c_{i t} d_{i t}^{\gamma}
$$

Since it is assumed to be constant over time, space and between actual and simulated scenarios, the impact of density on amenity value can be obtained by estimating the following regression using actual data:

$$
\operatorname{Ln}\left(C_{t i}\right)=\ln \left(c_{i t}\right)+\gamma \ln \left(d_{i t}\right)
$$




\section{$\underline{\text { House price and population }}$}

The second important assumption of the above approach is that with more affordable housing households would sort themselves into the same geographical distribution as observed in actual data. In practice, this appears to be somewhat unrealistic as the current population distribution appears to be driven primarily by amenity value. Removing the major determinant of geographical location choices could result in a very different distribution pattern. Nevertheless, this assumption is necessary in order to keep the simulated levels of housing development and consumption consistent with actual data. House prices have to remain constant in order for the assumption of the simulated housing demand being equal to its actual level to be valid.

An alternative approach is to use historical levels of housing stock and population to simulate current hosing demand. Past housing stock and population distribution are not influenced by the current levels of amenity values and, therefore, may give a better idea of what current housing demand would be like without them. Formally:

$$
W^{\prime \prime \prime}{ }_{i t}=r_{h} H_{i t}-\left(1-\left(1-\frac{\bar{W}_{t}}{\bar{H}_{t}}\right)\left(r_{p} d_{i t}\right)^{\gamma}\right)
$$

Where $r_{h}$ and $r_{p}$ are factors that adjusts house prices and population for the average growth rates. The important advantage of this approach is that wages are no longer influenced by the current levels of amenity values. This is critical especially in the light of the argument that this high amenity value is the main issue with the current levels of house prices.

The final assumption is that wages are not calculated based on the productivity of a location but as a residual of the exogenously set house prices and amenities. It is important to note that the two methods are equivalent so that:

$$
W^{\prime \prime \prime}{ }_{i t}=A^{\prime \prime \prime}{ }_{i t} r_{(t-n)} K_{i(t-n)}=r_{h} H_{i t}-\left(1-\left(1-\frac{\bar{W}_{t}}{\bar{H}_{t}}\right)\left(r_{p} d_{i t}\right)^{\gamma}\right)
$$

\section{Data and variables}

The data used to implement the above approach comes mainly from the UK office of National statistics and the UK Land Registry and is collected for Local Authority Districts (LADs) in England. LADs are used because each district is a relatively uniform housing market. These are also the smallest areas for which data on wages is available. Although without migration and changes in commuting patterns the size of the basic geographical unit should not affect the overall results, it is important to note that many of the effects assumed in the previous section (such as congestion effects or house prices) are specific to local housing markets. An obvious challenge to the LAD approach is the possibility of interdistrict commuting affecting local housing demand. This issue is reconciled theoretically if commuting is assumed to be a cost and that all people want to live close to their workplaces. For example, in this study workers from a highly productive area are not attracted to live outside of their workplace area as amenity values across all locations are equal. If the opportunity to commute to a different location is considered as an amenity, then it is removed from the model. In practice, the problem is addressed by using house prices recorded (or based on) actual data which reflects the spatial equilibrium that involves commuting choices. Following the focus on where people live, wages are recorded at the place of residence to reflect the earning potential available to residents of particular geographical areas. As the earliest year for which wages at the place of residence are available is 2002 this is the first year in the sample. 


\section{House prices, wages, population and density}

The LAD-level wage data comes from the UK Office of National Statistics. This dataset excludes LADs for which a sufficient number of observations was unavailable or where changes of the geographical bounds did not allow tracking the data continuously. This limits the size of the sample to 337 districts ${ }^{6}$. Summary statistics available in tables 1 and 2 show large variances between locations and over time in virtually all variables. House prices are the average of all transaction prices in the area. Although house prices are strongly correlated with wages, there is a large proportion of their variance that is not explained in this way. Critically, the affordability ratio also varies significantly across both time and space. Table 1 lists the most and least affordable locations in England in 2002 and 2016 (the first and last year available in the sample). The five most unaffordable locations are London boroughs, while 5 districts in the North West have the lowest values of the ratio. Despite differences in wages and population between the top and bottom five locations, it is apparent that the difference in affordability is disproportionally large.

Table 1. The most and least affordable districts in England in 2002 and 2016.

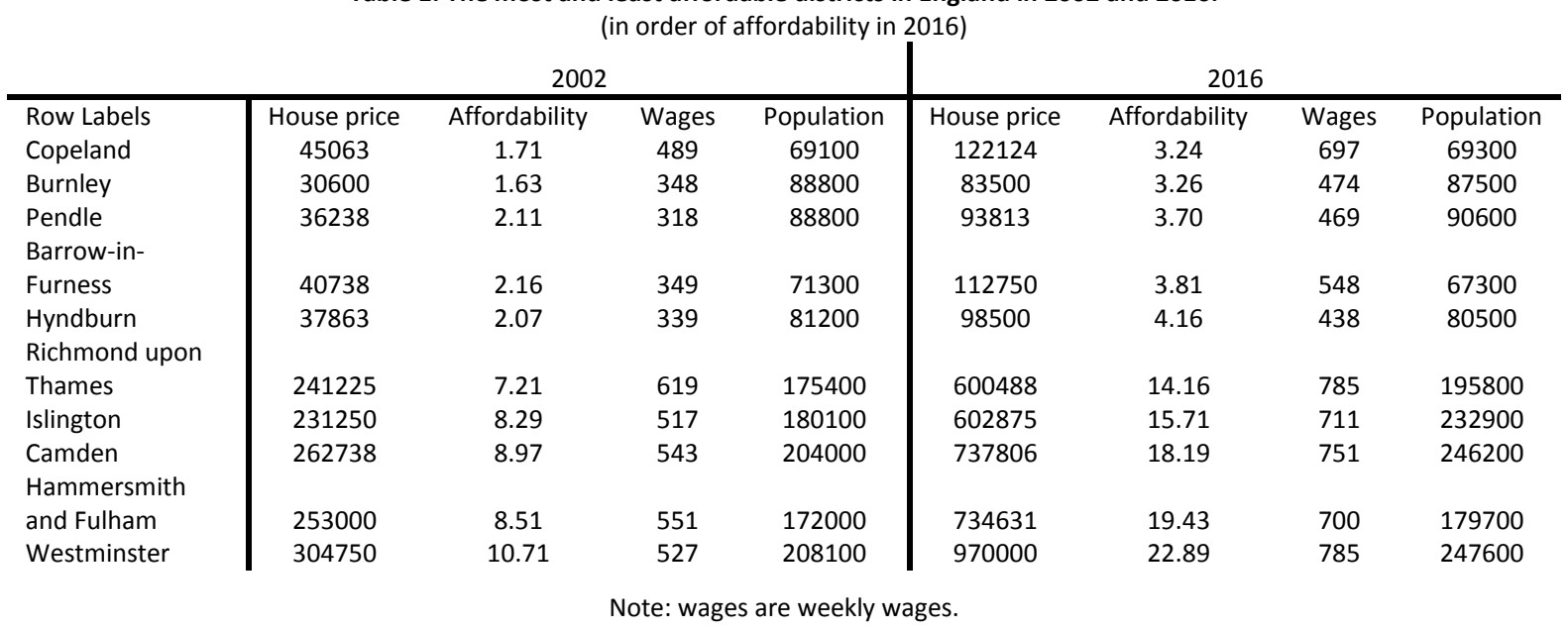

Table 2 shows that between 2002 and 2016 the highest increase in the affordability ratio occurred in London, where productivity was the lowest and wages grew slowly but house prices increased disproportionally fast. While many blame the affordability crisis on rising house prices there is little evidence to support this claim. For example, in the North East houses became more much more expensive but the change in affordability was modest. This is likely a result of productivity and wages increasing accordingly. Critically, 2016's average house prices in London are over 3.5 times higher than in the North East while wages are only 1.3 times higher, which shows the considerable difference in amenity values between the two locations. The data shows that, as predicted in sections 2 and 3 , affordability changes when changes in house prices are not related solely to shifting wages.

\footnotetext{
${ }^{6}$ The sample excludes County Durham, Cheshire East, Cheshire West and Chester, Shropshire, Cornwall, Isles of Scilly, Central Bedfordshire, Northumberland, West Somerset, Wiltshire and the City of London.
} 
Table 2. Key variables in England by region in 2002 and 2016.

\begin{tabular}{|c|c|c|c|}
\hline Affordability & $\begin{array}{l}2016 \\
\text { Average }\end{array}$ & StdDev & $\begin{array}{l}\text { \% change } \\
2002-2016\end{array}$ \\
\hline $\begin{array}{l}\text { East Midlands } \\
\text { East of England } \\
\text { London } \\
\text { North East } \\
\text { North West } \\
\text { South East } \\
\text { South West } \\
\text { West Midlands } \\
\text { Yorkshire } \\
\text { Weekly wages }\end{array}$ & $\begin{array}{c}6.21 \\
8.53 \\
13.78 \\
5.05 \\
5.23 \\
9.64 \\
8.37 \\
6.34 \\
5.96\end{array}$ & $\begin{array}{l}1.01 \\
1.79 \\
4.25 \\
0.34 \\
1.06 \\
1.75 \\
1.39 \\
1.28 \\
1.51\end{array}$ & $\begin{array}{c}56 \% \\
62 \% \\
101 \% \\
62 \% \\
64 \% \\
58 \% \\
42 \% \\
45 \% \\
63 \%\end{array}$ \\
\hline $\begin{array}{l}\text { East Midlands } \\
\text { East of England } \\
\text { London } \\
\text { North East } \\
\text { North West } \\
\text { South East } \\
\text { South West } \\
\text { West Midlands } \\
\text { Yorkshire } \\
\text { Productivity }\end{array}$ & $\begin{array}{l}505.88 \\
571.25 \\
643.15 \\
489.37 \\
503.62 \\
587.68 \\
509.48 \\
521.90 \\
492.25\end{array}$ & $\begin{array}{l}54.90 \\
79.06 \\
70.44 \\
19.45 \\
53.32 \\
68.38 \\
37.77 \\
57.64 \\
33.93\end{array}$ & $\begin{array}{l}35 \% \\
37 \% \\
32 \% \\
43 \% \\
38 \% \\
33 \% \\
39 \% \\
38 \% \\
37 \%\end{array}$ \\
\hline $\begin{array}{l}\text { East Midlands } \\
\text { East of England } \\
\text { London } \\
\text { North East } \\
\text { North West } \\
\text { South East } \\
\text { South West } \\
\text { West Midlands } \\
\text { Yorkshire } \\
\text { House prices }\end{array}$ & $\begin{array}{l}0.28 \\
0.27 \\
0.13 \\
0.17 \\
0.22 \\
0.26 \\
0.26 \\
0.22 \\
0.18\end{array}$ & $\begin{array}{l}0.11 \\
0.10 \\
0.04 \\
0.06 \\
0.13 \\
0.09 \\
0.12 \\
0.11 \\
0.14\end{array}$ & $\begin{array}{l}21 \% \\
22 \% \\
12 \% \\
38 \% \\
33 \% \\
19 \% \\
27 \% \\
28 \% \\
26 \%\end{array}$ \\
\hline $\begin{array}{l}\text { East Midlands } \\
\text { East of England } \\
\text { London } \\
\text { North East } \\
\text { North West } \\
\text { South East } \\
\text { South West } \\
\text { West Midlands } \\
\text { Yorkshire }\end{array}$ & $\begin{array}{l}170,330 \\
267,144 \\
486,515 \\
133,536 \\
142,361 \\
309,506 \\
230,302 \\
179,633 \\
158,281\end{array}$ & $\begin{array}{c}37648 \\
82325 \\
195281 \\
11926 \\
34177 \\
83186 \\
41613 \\
45969 \\
40242 \\
\end{array}$ & $\begin{array}{c}110 \% \\
122 \% \\
166 \% \\
132 \% \\
126 \% \\
111 \% \\
98 \% \\
99 \% \\
122 \%\end{array}$ \\
\hline
\end{tabular}

There are large differences in density between districts but from figure 1 variations can also be seen across England's regions. Density is naturally linked with housing demand, productivity and the amenity value therefore it is not surprising that in figure 1 it appears to be high in areas where affordability ratios are high and figure 2 shows a positive correlation between the two across space. There is also a stark difference between the dispertion of affordability ratios across the least and most dense areas as the former become much more conentrated while the latter see much more varaince. 
Figure 1. Density (left) and affordability (right) in English districts in 2016.
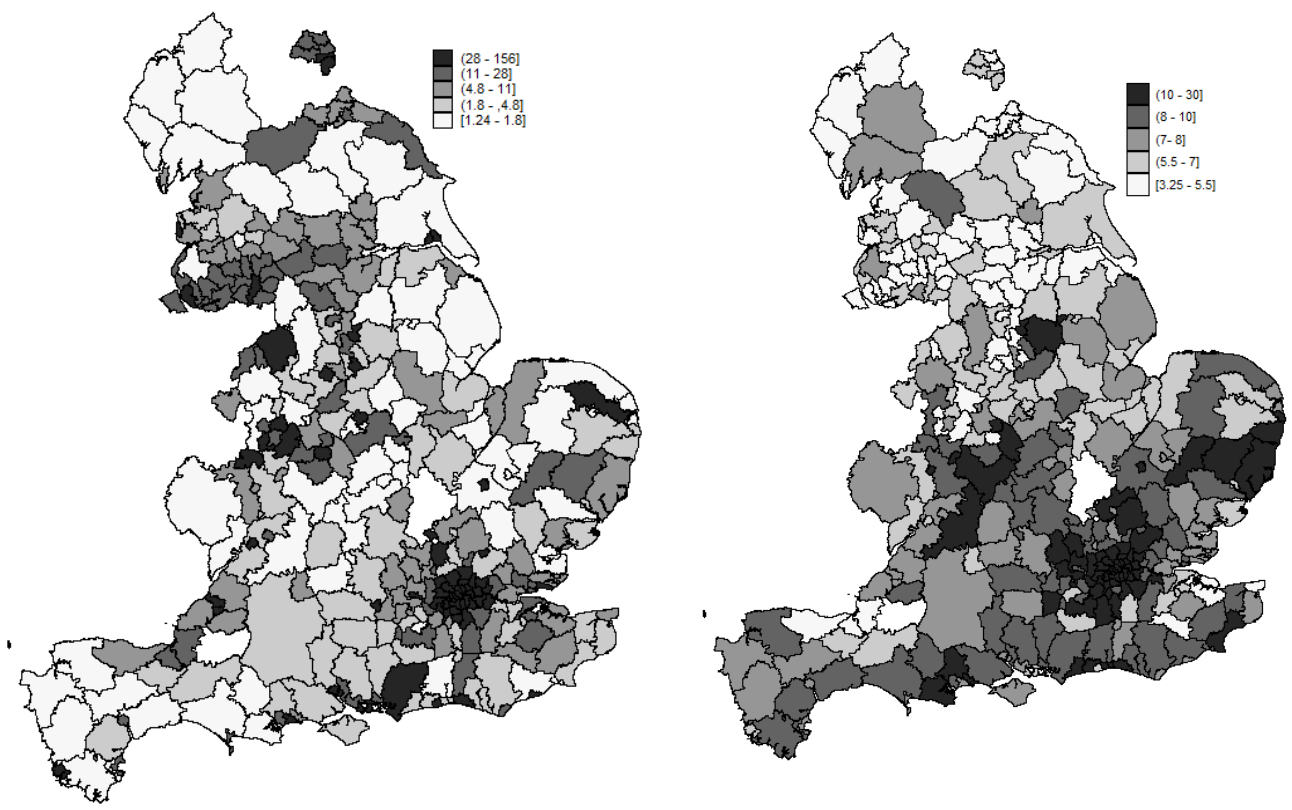

Figure 2. Density and affordability across England in 2002 (left) and 2016 (right).

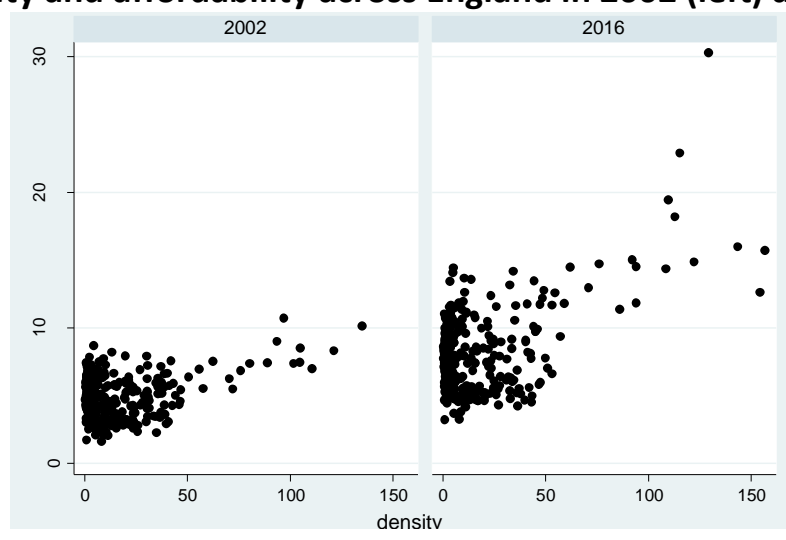

$\underline{\text { Historical data }}$

Historical data is based on year 1995. Data from the Nationwide Building Society (figure 3) shows that in 1995 affordability ratios were at their lowest on record and the differences across the most (Yorkshire) and least (London) affordable locations were the smallest. Therefore, in 1995 housing affordability ratios were arguably not a significant concern and, in most areas, were relatively close to the national average.

Figure 3 Affordability ratios in England 1983-2017 (source: Nationwide)

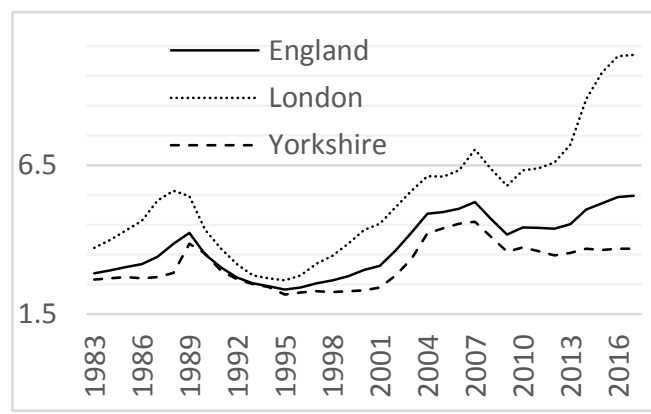




\section{Amenity value}

Adjusting the approach of Glaeser and Gyourko (2002) to a panel dataset the amenity value of a location is calculated as a residual from the following regression:

$$
H_{i t}=\beta_{s}\left(\text { location_fixed_effect } x W_{i t}\right)+\beta_{t}\left(\text { period_fixed_effect } x W_{i t}\right)+\beta_{w} W_{i t}+\varepsilon_{i t}
$$

Using an interaction term between wages and the time fixed effect reflects unobserved factors that affect what proportion of house prices is determined by wages in all locations over time (such as changes to interest rates). Conversely, the housing market in each location can be expected to be characterised by its own unique conditions (such as supply restrictions) and their impact is captured by the interaction of the location fixed effect with wages. As discussed earlier, the amenity value is also expected to have its own time and location fixed effects as well as to depend (non-linearly) on population density. The value of the congestion effect $\gamma$ can be obtained from estimating $\beta_{\gamma}$ in the following regression (where $\beta_{\gamma}=\gamma$ and $\mu$ in an error term with an expected value of zero):

$$
\operatorname{Ln}\left(\varepsilon_{i t}\right)=\beta_{s c} l o c a t i o n_{-} f i x e d \_e f f e c t+\beta_{t c} \text { period_fixed_effect }+\beta_{\gamma} \ln \left(d_{i}\right)+\mu_{i t}
$$

Figure 4 shows that interacting wages with time and location effects is necessary as the relationship between wages and prices changes over time and is location-specific. It also appears clear that in 2002 the relationship between wages and prices was much stronger than in 2016. This is consistent with the expectation that as affordability ratios increased with time, wages accounted for a smaller percentage of house prices. It is apparent that the relationship between wages and prices is much stronger in locations where affordability ratios are the lowest in the sample. This shows that affordability is a highly location-specific phenomenon.

Figure 4. Prices and wages in English districts.

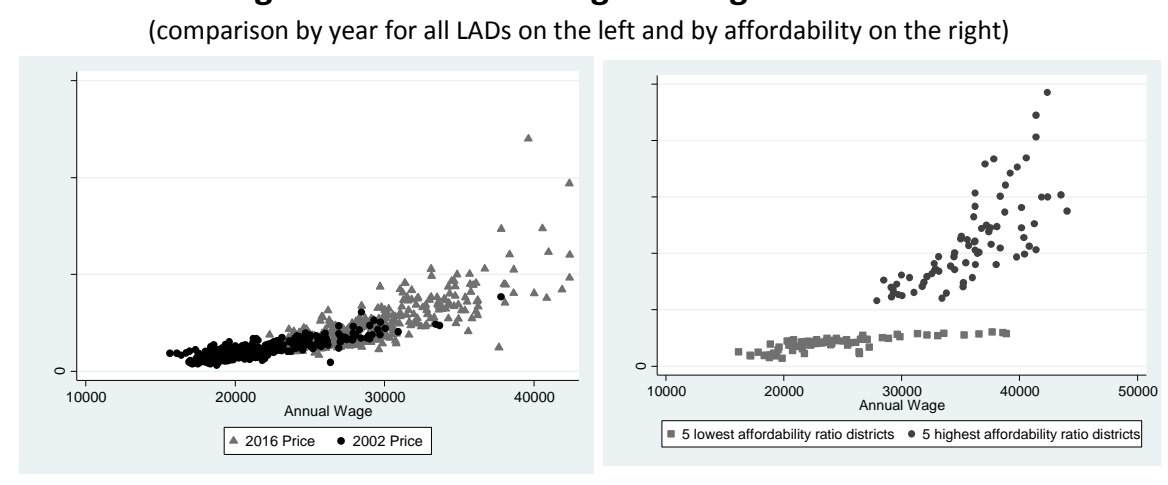

Numerous endogeneity issues have been reported with estimating the congestion effect using this regression. For example, it is likely that the level of amenities influences density (Rappaport 2008), or that both are simultaneously affected by exogenous factors (Wu et al. 2004). To control for these problems the equation is estimated using an approach applied in research of agglomeration effects suggested by Combes et al (2012) as well as Combes and Gobillon (2014). It is based on estimating the first difference form of the above equation and uses the Bartik instrument to adjust for endogeneity between population growth and amenity value.

\section{$\underline{\text { Total amenity value }}$}

Table 4 reports the results of a regression of house prices on wages and its interactions with time and location effects. As expected, after adjusting for the fixed-effects the model appears to fit the data much better. Although the coefficient relating to the average wage decreases when they are added, 
it needs to be noted that its effect in models 2 and 3 needs to be combined with the coefficient(s) of the interaction term(s).

Table 3. Wage contribution to house prices: regression results.

\begin{tabular}{llll} 
Model type & $\begin{array}{l}\text { Model 1 } \\
\text { Wage only }\end{array}$ & $\begin{array}{l}\text { Model 2 } \\
\text { Wage and time }\end{array}$ & $\begin{array}{l}\text { Model 3 } \\
\text { Wage, time and } \\
\text { location }\end{array}$ \\
\hline Wage & $391.79^{* * *}$ & $287.72^{* * *}$ & $163.52^{* * *}$ \\
St. Error & 1.88 & 8.39 & 18.36 \\
Wage Time-effect & No & Yes & Yes \\
Wage Location-effect & No & No & Yes \\
Adj R-squared & $90.15 \%$ & $91.07 \%$ & $98.44 \%$ \\
Number of obs. & 4,724 & 4,724 & 4,724 \\
Number of districts & 315 & 315 & 315 \\
& & &
\end{tabular}

In this study, the residual from model 3 of table 3 is treated as the overall amenity value. Table 4 gives the summary statistics for the residual. On average, house prices are higher than predicted by wages by around $£ 183,000$ and the highest difference is reported in Kensington in 2010 where the increase in house prices cannot be accounted for by changing wages and has to be attributed to increasing amenity value. The lowest amenity value is found in 2002 in Burnley where very low house prices compensate residents for low wages as well as the low amenity value.

Table 4. Summary statistics of the overall amenity value.

$\begin{array}{lcccc} & \text { Mean } & \text { Std. Dev. } & \text { Min } & \text { Max } \\ \text { Overall } & 183,169.5 & 84,503.84 & 19,313.08 & 806,529.4 \\ \text { Between } & & 76,300.62 & 64,856.39 & 722,988.8 \\ \text { Within } & & 36,548.15 & -10,680.48 & 324,045.9\end{array}$

Note: Between min \& max refer to the value in location i at time $t$ minus the average value across all locations at time $t$. Within min \& max refer to individual deviation from own averages, with global averages added back in.

The amenity value and agglomeration.

Table 5 shows that including time and fixed effects into the model of amenity value has a significant impact on estimation results. This is especially noticeable when location fixed effects are added and the estimated value of the agglomeration effect $\gamma$ changes in both sign and value. At this point the naïve results also differ from estimates obtained using the IV method. However, the importance of using an instrumental variable is noticeable especially in the last model where after removing all timeinvariable variables the agglomeration effect is estimated to be -0.151 which is consistent with expectations and with other studies (Cho et al. 2008, Ciccone 2002, Wheaton 1998). 
Table 5. Regression results: the intrinsic amenity value and the agglomeration effect.

\begin{tabular}{|c|c|c|c|c|c|c|c|c|}
\hline & \multicolumn{2}{|c|}{$\begin{array}{l}\text { Model 1: simple } \\
\text { regression }\end{array}$} & \multicolumn{2}{|c|}{$\begin{array}{l}\text { Model 2: time fixed } \\
\text { effects }\end{array}$} & \multicolumn{2}{|c|}{$\begin{array}{l}\text { Model 3: time and } \\
\text { location effects }\end{array}$} & \multicolumn{2}{|c|}{$\begin{array}{l}\text { Model 4: first difference } \\
\text { model with time effects }\end{array}$} \\
\hline \multicolumn{9}{|c|}{ Instrumental variable regressions } \\
\hline Log(density) & 0.027 & $* * *$ & 0.024 & $* * *$ & -0.863 & $* * *$ & -0.151 & $* * *$ \\
\hline St. Error & 0.005 & & 0.004 & & 0.061 & & 0.050 & \\
\hline Constant & 11.970 & $* * *$ & 11.449 & $* * *$ & 13.141 & $* * *$ & 0.093 & $* * *$ \\
\hline$\overline{\text { St. Error }}$ & 0.011 & & 0.023 & & 0.116 & & 0.003 & \\
\hline Time-effect & No & & Yes & & Yes & & Yes & \\
\hline Location-effect & No & & No & & Yes & & No & \\
\hline Model & Levels & & Levels & & Levels & & First differences & \\
\hline R-squared & & & & & & & & \\
\hline within & $7.0 \%$ & & $24.77 \%$ & & $94.32 \%$ & & $62.51 \%$ & \\
\hline between & - & & - & & $1.01 \%$ & & $18.21 \%$ & \\
\hline overall & - & & - & & $31.15 \%$ & & $60.17 \%$ & \\
\hline Number of obs. & 4,724 & & 4,724 & & 4,724 & & 4,408 & \\
\hline Number of districts & 315 & & 315 & & 315 & & 315 & \\
\hline \multicolumn{9}{|c|}{ Naïve regressions } \\
\hline Log(density) & 0.028 & $* * *$ & 0.025 & $* * *$ & -0.561 & $* * *$ & 0.263 & $* * *$ \\
\hline St. Error & 0.005 & & 0.004 & & 0.041 & & 0.169 & \\
\hline Constant & 11.968 & $* * *$ & 11.447 & $* * *$ & 12.564 & $* * *$ & 0.085 & $* * *$ \\
\hline St. Error & 0.011 & & 0.023 & & 0.079 & & 0.002 & \\
\hline Time-effect & No & & Yes & & Yes & & Yes & \\
\hline Location-effect & No & & No & & Yes & & No & \\
\hline Model & Levels & & Levels & & Levels & & First differences & \\
\hline R-squared & & & & & & & & \\
\hline within & $7.5 \%$ & & $24.81 \%$ & & $93.51 \%$ & & $63.18 \%$ & \\
\hline between & - & & - & & $0.82 \%$ & & $13.00 \%$ & \\
\hline overall & - & & - & & $0.35 \%$ & & $60.93 \%$ & \\
\hline Number of obs. & 4,724 & & 4,724 & & 4,724 & & 4,408 & \\
\hline Number of districts & 315 & & 315 & & 315 & & 315 & \\
\hline \multicolumn{9}{|c|}{$\begin{array}{l}\text { The estimated equation is: } \operatorname{Ln}\left(\varepsilon_{i t}\right)=\beta_{s c} \text { location_fixed_effect }+\beta_{t c} \text { period_fixed_effect }+\beta_{\gamma} \ln \left(d_{i}\right)+\mu_{i t} \\
\text { With each adjustment the distribution of } \mu_{i t} \text { is closer to the i.d.d. assumption. Residuals estimated in column } 4 \text { show no } \\
\text { correlation to any observable variables, pass normality tests with a mean of } 1.48 \mathrm{e}-12 \text { and standard deviation of } 0.05 \text {. Note } \\
\text { that model } 3 \text { demonstrates that location fixed effects are responsible for the majority of the variance in wages and } \\
\text { motivate the focus on the first-difference model. }\end{array}$} \\
\hline
\end{tabular}

Adopting the value of $\gamma$ as -0.151 allows splitting the amenity value in all districts into intrinsic values of locations and agglomeration effects. Ceteris paribus regions with high amenity values will attract higher density until the congestion effect removes the incentive to migrate.

\section{Results}

Table 6 shows actual wages, amenity values and productivity reported by ONS in 2016 and compares them to simulated values. The figures show that more affordable housing results in lower average values of amenities but higher wages and productivity. This is not only true for average LADs but also on a per-capita basis for the whole country. Column 3 shows that when a fixed average affordability ratio is imposed on all districts, the overall impact on wages in the economy is positive. It also demonstrates that productivity in England could be as much as $58 \%$ higher if the affordability ratio across all districts was equal. Naturally, productivity would increase the most in locations where houses are the most unaffordable (for example by as much as $84.6 \%$ in London). On the other hand, many affordable locations would see a decrease in productivity as their wages are would be lower. The 5 most affordable locations would see their productivity fall by $44.4 \%$. Allowing the affordability ratio to differ with density presents similar conclusions and suggests that the gain in productivity due to more affordable housing could increase productivity almost 5 fold while wages would rise by $356 \%$. Naturally, these estimates have purely theoretical meaning as they require a number of simplifying assumptions. Most importantly, the simulation uses the actual house price data which is inflated by 
amenity values which are at their historically highest levels. Assuming that they are simply replaced by higher wages results in overstating the required gain in productivity.

Table 6. Summary statistics of actual and simulated wages, amenity and productivity based on actual values.

\begin{tabular}{|c|c|c|c|c|c|c|c|c|}
\hline & \multicolumn{2}{|c|}{ Wages reported by ONS. } & \multicolumn{3}{|c|}{$\begin{array}{l}\text { Wages simulated by forcing the average } \\
\text { English affordability ratio from } 2016 \text { on all } \\
\text { LADs. }\end{array}$} & \multicolumn{3}{|c|}{$\begin{array}{l}\text { Wages simulated using } 2016 \text { 's house } \\
\text { prices and density spill over effects. }\end{array}$} \\
\hline & w & $A$ & $W^{\prime}$ & $A^{\prime}$ & $C^{\prime}$ & $W^{\prime \prime}$ & $A^{\prime \prime}$ & $C^{\prime \prime}$ \\
\hline Mean & 546.92 & 0.23 & 566.07 & 0.24 & $217,505.65$ & $1,751.57$ & 0.67 & $153,488.46$ \\
\hline Median & 534.30 & 0.23 & 496.88 & 0.21 & $190,918.53$ & $1,251.81$ & 0.54 & $145,197.37$ \\
\hline Standard Dev. & 76.85 & 0.11 & 298.22 & 0.15 & $114,588.62$ & $1,412.23$ & 0.48 & $67,986.38$ \\
\hline Range & 372.00 & 0.67 & $2,549.27$ & 0.93 & $979,527.38$ & $12,420.49$ & 4.37 & $452,275.44$ \\
\hline Minimum & 413.10 & 0.02 & 190.54 & 0.02 & $73,211.08$ & 468.47 & 0.07 & $52,408.72$ \\
\hline Maximum & 785.10 & 0.69 & $2,739.81$ & 0.94 & $1,052,738.46$ & $12,888.96$ & 4.44 & $504,684.16$ \\
\hline Country average & 547.61 & 0.12 & 572.05 & 0.19 & $219,804.14$ & $1,949.38$ & 0.57 & $145,428.33$ \\
\hline
\end{tabular}

Notes: the country average is calculated by taking an average value per capita across all districts and averaging this number by people (rather than districts). Productivity is calculated based on wages (actual W for A, simulated W' for A' and simulated W" for A") based on the production function presented in equation 1 in section 3 . Amenity value is calculated using the spatial equilibrium model. $C^{\prime \prime}$ includes density spillover effects. Note that house prices are constant across all 3 scenarios.

This problem is addressed by using house prices and population based on 1995 data. Table 7 shows that when this approach is used the results differ considerably. First, when house prices are based on a more spatially uniform growth rates the variance in house prices across districts is much lower. The most expensive simulated houses are also significantly cheaper than in the actual data. This means that actual wages account for more of the simulated than of the actual house prices and suggest that the average affordability ratio would be as low as 2.8 with a standard deviation across districts of only 2.13. However, under simulated house prices and population levels a different pattern of wage growth is also required. Across England average wages determined by the actual affordability ratio and simulated densities are not statistically different. The simulated values do, however, vary much more across space and London boroughs appear to offer very high wages. This is not unexpected as those locations are the most densely populated areas in the country and have very high house prices. In order to compensate its residents for the loss in utility caused by these factors wages have to be high. The 2016's average simulated annual wage in London $(£ 58,689)$ is almost twice as high as the country's average $(f 29,970)$ which shows that in the simulated scenario the city remains a centre of economic activity. Unlike in the actual data, in the simulation residents are not deriving any heterogeneous utility from living in London thus their wages have to compensate them for high house prices and congestion. This requires higher productivity. Indeed the simulated productivity of English districts has a very different spatial distribution than what is observed in actual data.

The results suggest per-capita average wage in England in 2016 would be higher by around $9.3 \%$ if the spatial distribution of housing demand and population from 1995 remained unchanged. At the same time, productivity would increase by as much $66.7 \%$ as the spatial distribution of economic activity would result in lower concentration of population in areas that currently offer the most attractive amenities. Consequently, the simulated productivity differs significantly from actual values due to the different geographical distribution of economic activity (see figure 5). 
Table 7. Summary statistics of actual and simulated wages, amenity and productivity based on actual values.

\begin{tabular}{|c|c|c|c|c|c|}
\hline & \multicolumn{2}{|c|}{ Wages reported by ONS. } & \multicolumn{3}{|c|}{$\begin{array}{l}\text { Wages simulated using population levels } \\
\text { and house prices extrapolated from their } \\
1995 \text { values. }\end{array}$} \\
\hline & $w$ & $A$ & $W^{\prime \prime \prime}$ & $A^{\prime \prime \prime}$ & $C^{\prime \prime \prime}$ \\
\hline \multicolumn{6}{|l|}{2016} \\
\hline Mean & 546.92 & 0.23 & 555.42 & 0.24 & $53,142.83$ \\
\hline Median & 534.30 & 0.23 & 496.75 & 0.21 & $50,375.35$ \\
\hline Standard Dev. & 76.85 & 0.11 & 274.44 & 0.14 & $17,401.58$ \\
\hline Range & 372.00 & 0.67 & $2,438.77$ & 0.94 & $95,237.15$ \\
\hline Minimum & 413.10 & 0.02 & 212.69 & 0.03 & $24,687.89$ \\
\hline Maximum & 785.10 & 0.69 & $2,651.46$ & 0.97 & $119,925.04$ \\
\hline Country average & 547.61 & 0.12 & 598.65 & 0.20 & $49,188.64$ \\
\hline
\end{tabular}

Notes: the country average is calculated by taking an average value per capita across all districts and averaging this number by people (rather than districts). Productivity is calculated based on wages (actual $W$ for $A$, simulated $W^{\prime \prime \prime}$ for $A^{\prime \prime \prime}$ ) based on the production function presented in equation1. Amenity value is calculated using the spatial equilibrium model and includes density spillover effects. Note that house prices are constant across both scenarios. Extrapolation of house prices and population from 1995 values is based on national growth rates of both values.

Figure 5. Actual (left) and simulated (right) productivity in England in 2016.
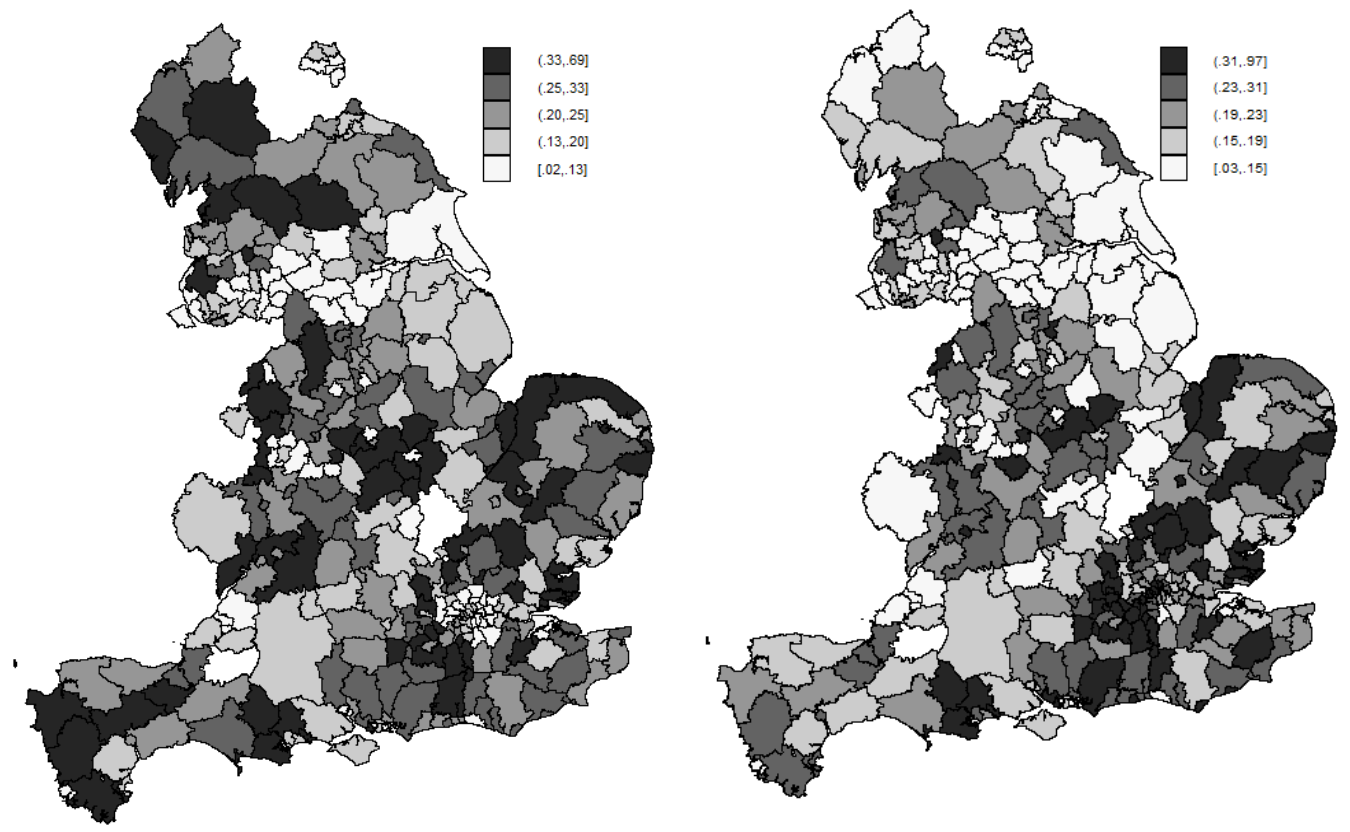

Notes: Actual values are calculated by diving actual wages by actual population (both reported by ONS). Simulated productivity is A"' and is calculated by dividing simulated wage (W'"') by simulated population levels (1995's levels extrapolated using average growth rate).

Notably, figure 5 shows that actual productivity is low in locations where density is high. This includes major cities and all London boroughs. Their surrounding areas on the other hand show high productivity as their residents work in densely populated location but prefer to live in elsewhere (De Goei et al. 2010). In the simulated values the trend is reversed as the most productive districts are the ones with the highest density while their surrounding areas are less productive. This is a result of removing most of the amenity value (including commuting opportunities) from house prices and replacing it with higher wage. 


\section{Conclusions}

The key contribution of this study is to note that the affordability crisis is not strictly a result of rising house prices or limited housing supply. Instead the paper notes that affordability is adversely affected when increases in demand are not driven by wages. Linking growing affordability ratios to an increase amenity values allows taking a new perspective on the problem and its economic consequences.

This approach offers interesting implications for polices aimed at addressing the affordability problem. If it is not caused solely by inadequate housing supply, then perhaps focusing on building additional dwellings is not the optimal response. Instead, it may be useful to consider polices that focus on managing housing demand. Critically, demand-focused resolutions of the affordability crisis do not require the demand to be lower but simply to be driven more by wages. In this light, policies aimed at reducing amenity value and increasing wages of the most unaffordable locations could help to address the problem. However, more research is needed to recommend what amenities need to be targeted in specific areas and how policies should be designed.

The study also notes that while heterogeneity between households may fully explain differences between price to wage ratios across locations, the detrimental economic effects of the affordability crisis are not caused simply by differences in preferences for amenities but by varying abilities to pay for accessing them. Simulation results clearly show that the most significant limitation imposed on regional economies by over-inflated amenity values is the constraint it places on household migration and, consequently, on labour supply. This suggests that housing affordability is not only a social and political issue but that it also has a significant economic cost as it may limit productivity growth.

\section{References}

Barker, K. (2008). Planning policy, planning practice, and housing supply. Oxford Review of Economic Policy, 24(1), 34-49.

Bernstein, H. (2000). Colonialism, capitalism, development. Poverty and development into the 21st century, 241-270.

Bramley, G. (2007). The sudden rediscovery of housing supply as a key policy challenge. Housing Studies, 22(2), 221-241.

Brasington, D. M., \& Hite, D. (2005). Demand for environmental quality: a spatial hedonic analysis. Regional science and urban economics, 35(1), 57-82.

Cho, S. H., Poudyal, N. C., \& Roberts, R. K. (2008). Spatial analysis of the amenity value of green open space. Ecological Economics, 66(2), 403-416.

Ciccone, A. (2002). Agglomeration effects in Europe. European Economic Review, 46(2), 213-227.

Combes, P. P., \& Gobillon, L. (2014). The empirics of agglomeration economies.

Combes, P. P., Duranton, G., Gobillon, L., Puga, D., \& Roux, S. (2012). The productivity advantages of large cities: Distinguishing agglomeration from firm selection. Econometrica, 80(6), 2543-2594.

De Goei, B., Burger, M. J., Van Oort, F. G., \& Kitson, M. (2010). Functional polycentrism and urban network development in the Greater South East, United Kingdom: Evidence from commuting patterns, 1981-2001. Regional Studies, 44(9), 1149-1170.

DETR Department of Environment, Transport and the Regions (2000) Quality and Choice: A Decent Home for All (London: DETR/DSS).

Evans, A. W. (1990). The assumption of equilibrium in the analysis of migration and interregional differences: a review of some recent research. Journal of Regional Science, 30(4), 515-531. 
Fingleton, B. (2008). Housing supply, housing demand, and affordability. Urban Studies, 45(8), 15451563.

Fingleton, B., Fuerst, F., \& Szumilo, N. (2018). Housing affordability: Is new local supply the key?. Environment and Planning A: Economy and Space, 0308518X18798372.

Gan, Q., \& Hill, R. J. (2009). Measuring housing affordability: Looking beyond the median. Journal of Housing economics, 18(2), 115-125.

Gibbons, S., Mourato, S., \& Resende, G. M. (2014). The amenity value of English nature: a hedonic price approach. Environmental and Resource Economics, 57(2), 175-196.

Glaeser, E. L., \& Gyourko, J. (2002). The impact of zoning on housing affordability (No. w8835). National Bureau of Economic Research.

Glaeser, E. L., Gyourko, J., \& Saks, R. E. (2005). Urban growth and housing supply. Journal of Economic Geography, 6(1), 71-89.

Graves, P. E., \& Mueser, P. R. (1993). The role of equilibrium and disequilibrium in modeling regional growth and decline: a critical reassessment. Journal of Regional Science, 33(1), 69-84.

Gyourko, J., Mayer C., \& Sinai T. (2013). "Superstar Cities." American Economic Journal: Economic Policy, 5(4): 167-99.

Hancock, K. E. (1993). 'Can Pay? Won't Pay?'or Economic Principles of'Affordability'. Urban studies, 30(1), 127-145.

Hilber, C. A. (2015). The economic implications of house price capitalization: a synthesis. Real Estate Economics, 45(2), 301-339.

Hilber, C. A., \& Vermeulen, W. (2016). The impact of supply constraints on house prices in England. The Economic Journal, 126(591), 358-405.

Hsieh, C. T., \& Moretti, E. (2015). Why do cities matter? Local growth and aggregate growth (No. w21154). National Bureau of Economic Research.

Hughes, G. \& McCormick, B. (2000) "Housing Policy and Labour Market Performance", ODPM.

Jeanty, P. W., Partridge, M., \& Irwin, E. (2010). Estimation of a spatial simultaneous equation model of population migration and housing price dynamics. Regional Science and Urban Economics, 40(5), 343-352.

Lazrak, F., Nijkamp, P., Rietveld, P., \& Rouwendal, J. (2014). The market value of cultural heritage in urban areas: an application of spatial hedonic pricing. Journal of Geographical Systems, 16(1), 89114.

McMillen, D. P. (2008). Changes in the distribution of house prices over time: Structural characteristics, neighborhood, or coefficients?. Journal of Urban Economics, 64(3), 573-589.

Meen, G. (2000). Housing cycles and efficiency. Scottish Journal of Political Economy, 47(2), 114-140. Meen, G. (2011). A long-run model of housing affordability. Housing Studies, 26(7-8), 1081-1103.

Meen, G., \& Andrew, M. (2008). Planning for housing in the post-Barker era: affordability, household formation, and tenure choice. Oxford Review of Economic Policy, 24(1), 79-98.

Moore, E., \& Skaburskis, A. (2004). Canada's increasing housing affordability burdens. Housing studies, 19(3), 395-413.

Muellbauer, J. \& Murphy, A. (1997) "Booms and Busts in the UK Housing Market", Economic Journal, 107(445), pp. 1701-1727.

Muellbauer, J., \& Murphy, A. (2008). Housing markets and the economy: the assessment. Oxford review of economic policy, 1-33.

ONS (2017). Housing affordability in England and Wales: 1997 to 2016. Available at:

https://www.ons.gov.uk/releases/housingaffordabilityinenglandandwales1997to2016

Rappaport, J. (2008). Consumption amenities and city population density. Regional Science and Urban Economics, 38(6), 533-552.

Roback, J. (1982). Wages, Rents, and the Quality of Life, The Journal of Political Economy, vol. 90, no, 6, pp. 1257-1278.

Sá, F. (2015). Immigration and House Prices in the UK. The Economic Journal, 125(587), 1393-1424. 
Shiller, R. J. (2007). Understanding recent trends in house prices and home ownership (No. w13553). National Bureau of Economic Research.

Stone, M. E. (2006). What is housing affordability? The case for the residual income approach. Housing policy debate, 17(1), 151-184.

Szumilo, N., \& Vanino, E. Are Government and Bank Loans Substitutes or Complements? Evidence from Spatial Discontinuity in Equity Loans. Real Estate Economics.

Wheaton, W. C. (1990). Vacancy, search, and prices in a housing market matching model. Journal of Political Economy, 98(6), 1270-1292.

Wheaton, W. C. (1998). Land use and density in cities with congestion. Journal of urban economics, 43(2), 258-272.

Whitehead, C. M. (2007). Planning policies and affordable housing: England as a successful case study?. Housing Studies, 22(1), 25-44.

Wright, W. C., \& Eppink, F. V. (2016). Drivers of heritage value: A meta-analysis of monetary valuation studies of cultural heritage. Ecological Economics, 130, 277-284.

Wu, J., Adams, R. M., \& Plantinga, A. J. (2004). Amenities in an urban equilibrium model: Residential development in Portland, Oregon. Land Economics, 80(1), 19-32. 


\section{Appendix}

\begin{tabular}{|c|l|}
\hline \multicolumn{2}{|c|}{ Table A. Variables and labels. } \\
\hline$a_{i t}$ & Intrinsic amenity value \\
\hline$A_{i t}$ & Productivity \\
\hline$c_{i t}$ & Intrinsic productivity \\
\hline$d$ & Density \\
\hline$\gamma$ & Density spill over of amenity \\
\hline $\bar{H}_{t}$ & Average house price paid in England \\
\hline$H_{i t}$ & House transaction prices \\
\hline$i$ & Location - Local authority district \\
\hline$K_{i t}$ & Population \\
\hline$L_{i t}$ & Labour \\
\hline$\omega$ & Density spill over of productivity \\
\hline$r_{h}$ & Growth of average house prices in England \\
\hline$r_{p}$ & Growth of population in England \\
\hline$s$ & Constant set by credit markets \\
\hline$t$ & Time (year) \\
\hline$W_{c}$ & Wages set by marginal cost of production \\
\hline$W_{m}$ & Wage required to obtain a mortgage \\
\hline $\bar{W}_{t}$ & Average wage in England \\
\hline$W^{\prime}{ }_{i t}$ & Local wage simulated using the average affordability ratio in England \\
\hline$W^{\prime \prime} i t$ & Local wage simulated using density spill over \\
\hline$W^{\prime \prime \prime}{ }_{i t}$ & Local wage simulated using 1995 values and average growth rates \\
\hline
\end{tabular}

